\title{
KEAMANAN DOKUMEN MENGGUNAKAN ALGORITMA ADVANCED ENCRYPTION STANDARD (AES)
}

\author{
Joko Handoyo ${ }^{1}$, Yulieo Muchti Subakti ${ }^{2}$ \\ ${ }^{1}$ Program Studi Teknik Elektro Sekolah Tinggi Teknologi Ronggolawe Cepu \\ 2 Program Studi Teknik Elektro Sekolah Tinggi Teknologi Ronggolawe Cepu
}

\section{Article Info:}

Dikirim: 27 September 2020

Direvisi: 15 Desember 2020

Diterima: 30 Desember 2020

Tersedia Online: 31 Desember 2020

Penulis Korespondensi: Joko Handoyo

Program Studi Teknik Elektro Sekolah Tinggi Teknologi

Ronggolawe Cepu

Email: jokohandoyo@sttrcepu.ac.id

\begin{abstract}
Abstrak: Masalah keamanan merupakan salah satu aspek penting dari sebuah sistem informasi, akan tetapi masalah keamanan seringkali mendapatkan perhatian dari pemilik dan pengelola sistem informasi. Salah satu kasus yang terjadi adalah kebocoran data pemilih di Indonesia sebanyak 2,3 juta. Data berukuran 2,36 GB yang berisi data dalam format file PDF. Untuk mengatasi masalah tersebut dapat dilakukan dengan mengamankan data dengan menggunakan konsep kriptografi. Dalam bidang kriptografi terdapat dua konsep yang sangat penting yaitu enkripsi dan deskripsi. Keamanan data diperlukan untuk mencegah informasi yang disimpan dibaca atau dibuka oleh pihak yang tidak berkepentingan. Untuk menghindari penyadapan atau pembajakan file yang berisi informasi penting bagi pengguna dan untuk menjaga integritas tersebut, maka diperlukan algoritma yang dapat melindungi file adalah Algoritma Advanced Standard Encryption (AES). Tujuan dari penelitian ini adalah untuk mengamankan dokumen dengan menggunakan algoritma AES. File yang melalui uji enkripsi akan berubah menjadi file yang tidak dapat dibaca, file tersebut dapat kembali ke bentuk aslinya jika melalui proses dekripsi menggunakan kunci yang sama pada saat enkripsi. Dari hasil penelitian telah dibuktikan bahwa isi dari file awal yang mengalami proses enkripsi, kemudian melalui proses dekripsi, akan kembali ke file aslinya..
\end{abstract}

Kata kunci: keamanan; dokumen; kriptografi; advanced standard encryption (AES).

\begin{abstract}
Security issues are one of the important aspects of an information system, but security issues often get the attention of owners and managers of information systems. One of the cases that occurred was the leakage of voter data in Indonesia as many as 2.3 million. The data is 2.36 GB in size which contains data in PDF file format. To solve this problem, it can be done by securing the data by using the concept of cryptography. In the field of cryptography, there are two very important concepts, namely encryption and description. Data security is necessary to prevent the stored information from being read or opened by unauthorized parties. To avoid tapping or hijacking files that contain important information for users and to keep that integrity safe, an algorithm that can protect files is needed is the Advanced Standard Encryption (AES) Algorithm. The purpose of this research is to secure documents using the AES algorithm. Files that go through the encryption test will turn into unreadable files, the files can return to their original form if they go through the decryption process using the same key during encryption. From the research results, it has been proven that the contents of the initial file undergoing an encryption process, then undergoing a decryption process, will return to the original file.
\end{abstract}

Keywords: security; documents; cryptography; advanced standard encryption (AES). 


\section{PENDAHULUAN}

Perkembangan teknologi sangat dibutuhkan oleh kehidupan manusia dalam setiap kegiatannya. Ilmu teknologi yang semakin berkembang khususnya dalam bidang komputer berkaitan dengan semakin banyaknya penggunaan sistem komputer. Perkembangan ini pun berpengaruh terhadap keamanan komputer khususnya pengamanan file dokumen atau data. Kemananan dari data diperlukan untuk menjaga agar informasi yang tersimpan tidak dapat dibaca atau dibuka oleh pihak yang tidak berhak.

Masalah keamanan merupakan salah satu aspek penting dari sebuah sistem informasi, akan tetapi masalah keamanan sering kali mendapat perhatian dari pemilik dan pengelola sistem informasi. Sejak lahirnya konsep open sistem, semua data dapat mengalir bebas melewati jaringan komputer. Berbagai cara dilakukan untuk mendapatkan data atau informasi mulai dari yang mudah hingga dengan cara yang rumit. Salah satu kasus yang terjadi adalah bocornya data pemilih di Indonesia sebanyak 2,3 juta. Data tersebut berukuran 2,36 GB yang berisi data dengan format file PDF. Untuk mengatasi masalah ini dapat dilakukan dengan cara mengamankan data tersebut dengan menggunakan konsep Kriptografi.

Kriptografi adalah bidang ilmu yang mempelajari bagaimana cara mengamankan suatu pesan atau informasi [1]. Dalam bidang kriptografi terdapat dua konsep yang sangat penting yaitu enkripsi dan deskripsi. Proses pengiriman pesan akan melalui proses enkripsi untuk mengubah teks asli (plaintext) menjadi teks sandi (ciphertext). Dengan proses enkripsi suatu informasi akan menjadi lebih sulit untuk diketahui oleh orang yang tidak berhak. Keamanan tersebut diperlukan untuk menghindari adanya penyadapan atau pembajakan terhadap file yang mengandung informasi penting bagi penggunanya dan menjaga integritas tersebut agar tetap aman, maka dibutuhkan sebuah algortima yang dapat memproteksi file adalah Algoritma Advanced Standard Encryption (AES). AES adalah algoritma simetris 2 yang menggunakan kunci yang sama untuk proses enkripsi dan dekripsi. Algoritma AES memiliki tiga pilihan kunci yaitu: AES 128-bit, AES 192-bit, dan AES 256-bit. Dari pernyataan diatas, penulis menyusun laporan tugas akhir ini dengan berjudul "Keamanan Dokumen Menggunakan Algoritma Advanced Encryption Standard (AES)”.

\section{KERANGKA TEORI}

\subsection{Sistem}

Sistem dapat diartikan sebagai suatu kumpulan atau himpunan dari unsur, komponen, atau variabel yang terorganisir, saling berinteraksi, saling bergantung satu sama lain dan terpadu. Teori sistem secara umum yang pertama kali diuraikan oleh kenneth Boulding, terutama menekan pentingnya perhatian terhadap setiap bagian yang membentuk sebuah sistem [2].

\subsection{Dokumen}

Dokumen merupakan suatu sarana transformasi informasi dari satu orang ke orang lain atau dari suatu kelompok ke kelompok lain. Dokumen meliputi berbagai kegiatan yang diawali dengan bagaimana suatu dokumen dibuat, dikendalikan, diproduksi, disimpan, didistribusikan, dan digandakan. Dokumen sangat penting, baik dalam kehidupan sehari-hari, organisasi, maupun bisnis [3].

\subsection{Hypertext preprocessor (PHP)}

PHP adalah bahasa script yang dapat ditanamkan atau disisipkan ke dalam HTML. PHP banyak dipakai untuk membuat program situs web dinamis. $P H P$ sering juga digunakan untuk membangun sebuah $C M S$. $P H P$ merupakan bahasa pemrograman yang bisa digunakan untuk membuat halaman $H T M L$. File .php yang dibuat akan di proses di dalam server, sedangkan halaman yang akan dikirim ke browser pengunjung hanyalah tampilan $H T M L$. Pemrograman $P H P$ sangat cocok untuk dikembangkan dalam lingkungan web, karena $P H P$ bisa dilekatkan pada script HTML atau sebaliknya. PHP dikhususkan untuk pengembangan web dinamis, maksudnya adalah bahwa PHP mampu menghasilkan website yang secara terus-menerus bisa berubah-rubah hasilnya sesuai dengan pola yang diberikan, hal tersebut tergantung dari permintaan client browsernya (bisa menggunakan browser opera, internet explorer, mozzila, dan lain-lain). Dan biasanya pembuatan web dinamis dengan PHP berhubungan erat dengan database sebagai sumber data yang akan ditampilkan [4].

\subsection{Database}

Database yaitu kumpulan data yang berhubungan satu dengan lainnya, dan tersimpan di luar komputer dan menggunakan perangkat lunak tertentu untuk memanipulasinya. Database merupakan komponen yang penting didalam sistem, karena berfungsi sebagai penyedia informasi bagi para penggunanya [5].

\section{$2.5 \quad M y S Q L$}


$M y S Q L$ adalah sebuah program database server yang mampu menerima dan mengirimkan datanya dengan sangat cepat, multi user serta mengguankan perintah standar Structured Query Language (SQL). MySQL memiliki dua bentuk lisensi, yaitu freesoftware dan shareware. MySQL yang biasa kita gunakan adalah MySQL freesoftware yang berada di bawah lisensi GNU/GPL. MySQL merupakan sebuah database server yang free, artinya kita bebas menggunakan database ini untuk keperluan pribadi atu usaha tanpa harus membeli atau membayar lisensinya [5].

\subsection{Kriptografi}

Kriptografi yaitu berasal dari bahasa yunani, crypto dan graphia. Crypto artinya secret (rahasia) dan graphia artinya writing (tulisan). Jadi, kriptografi dapat diartikan menjadi tulisan rahasia. Kriptografi adalah ilmu tentang teknik enkripsi yang dimana data diacak dengan suatu kunci enkripsi menjadi sesuatu yang sulit dibaca oleh orang yang tidak mempunyai kunci dekripsi. Kriptografi merupakan teknik pengamanan informasi dilakukan dengan mengolah informasi awal (plaintext) dengan suatu kunci dan menggunakan metode enkripsi tertentu sehingga dapat menghasilkan informasi baru (ciphertext) yang tidak dapat dibaca. Dan ciphertext tersebut dapat dikembalikan menjadi plaintext kembali dengan cara proses dekripsi [1].

\subsection{Algoritma Advanced Enryption Standard (AES)}

Algoritma AES adalah algoritma kritografi yang dapat mengenkripsi dan mendekripsi data dengan panjang kunci yang bervariasi, yaitu 128 bit, 192 bit, dan 256 bit. Proses enkripsi algoritma AES terdiri dari 4 jenis transformasi bytes, yaitu SubBytes, ShiftRows, MixColumns, dan AddRoundKey. Awal proses enkripsi, input yang telah disalin ke dalam state akan mengalami transformasi byte AddRoundKey. Setelah itu, state akan mengalami transformasi SubBytes, ShiftRows, MixColumns, dan AddRoundKey secara berulang-ulang sebanyak Nr. Proses ini dalam algoritma AES disebut dengan round function. Round terakhir agak berbeda dengan round sebelumnya dimana pada round terakhir, state tidak mengalami transformasi MixColumns [6].

\section{METODOLOGI PENELITIAN}

Pada tahap metodologi dilakukan proses studi literature. Setelah itu pengolahan data (perancangan sistem) dan analisi dari hasil sistem tersebut.

\subsection{Desain Penelitian}

Diagram alir penelitian diperlukan untuk melakukan perencanaan proses, analisis proses, dan dokumentasi proses sebagai pedoman untuk melakukan penelitian, berikut diagram alir penelitian yang ditampilkan pada Gambar 1 :

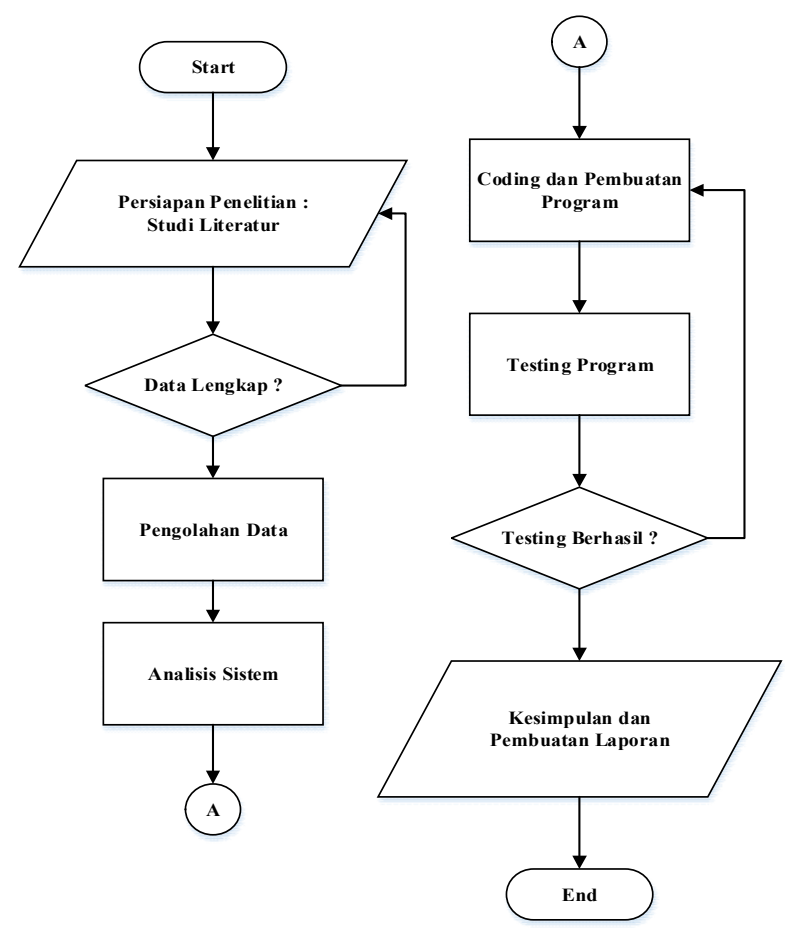

Gambar 1. Diagram Alir Penelitian

\subsubsection{Metode Pengumpulan Data}


Dalam penelitian ini metode pengumpulan data yang digunakan adalah studi literatur. Studi literatur ini dilakukan oleh penulis untuk mengumpulkan sumber-sumber tertulis, dengan cara membaca, mempelajari dan mencatat hal-hal penting yang berhubungan dengan masalah yang sedang diteliti.

\subsubsection{Sumber Data}

Data yang digunakan dalam penelitian kali ini merupakan data sekunder dimana data tersebut diambil dari www.cnbcindonesia.com.

\subsection{Analisi dan Perancangan Sistem}

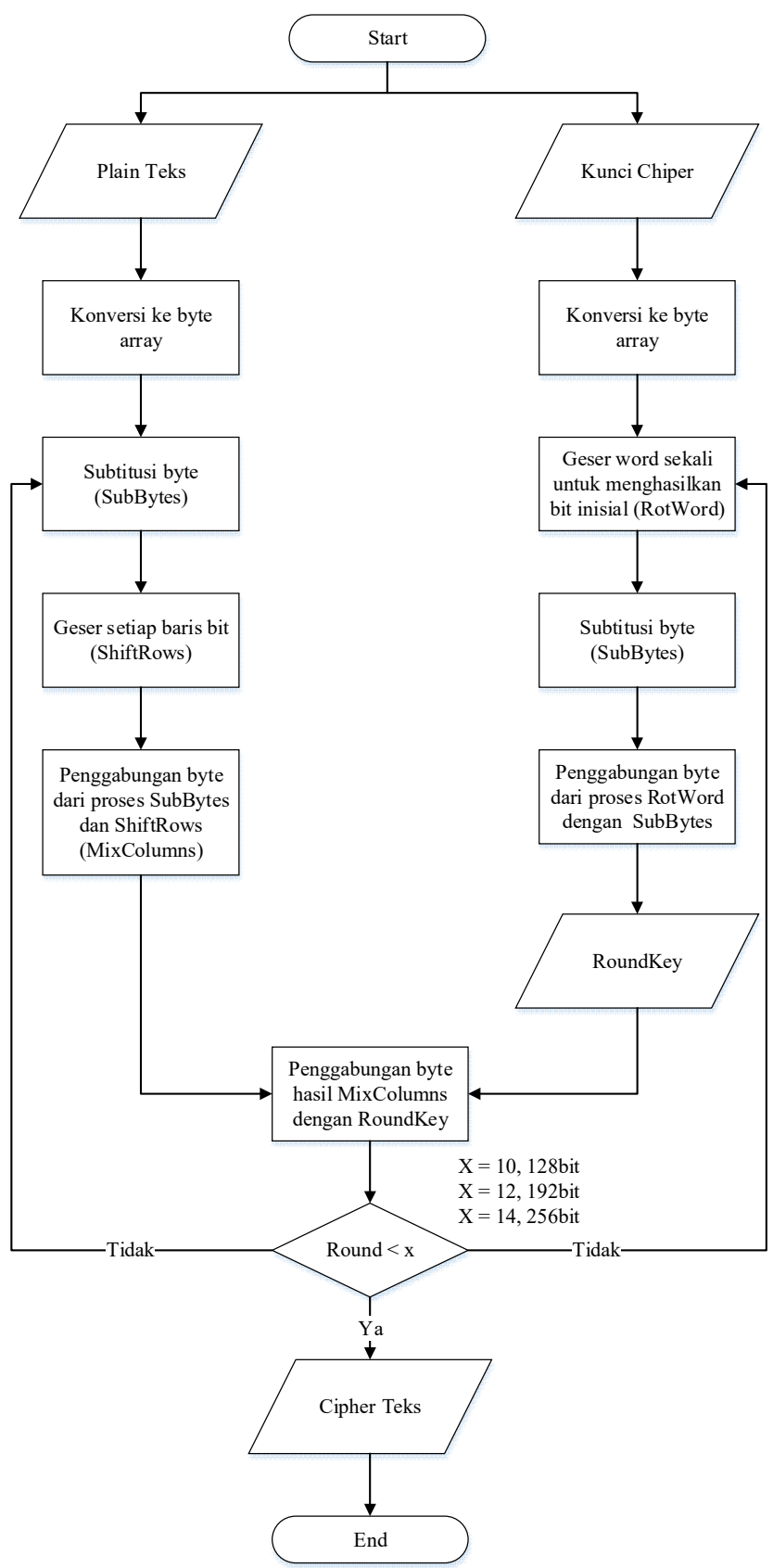

Gambar 2. Diagram Alir AES

Pada penelitian ini, algoritma Advanced Encryption Standard (AES) diimplementasikan sebagai pengamananform dokumen pada website. Dalam proses pengiriman dokumen, ketika dokumen dan password dimasukkan maka akan otomatis di enkripsi. Untuk memulai proses enkripsi siapkan 2 buah array berukuran $4 \mathrm{x} 4$ bernama Plaintext dan Key. Plaintext dan key tersebut dikonversikan ke dalam bentuk bit menggunakan kode ASCII. Lalu Konversikan kode ASCII tersebut ke dalam heksadesimal. 


\subsubsection{Struktur Tabel}

a) Tabel user

Tabel 1. Struktur tabel user

\begin{tabular}{lcll}
\hline \multicolumn{1}{c}{ Field } & Type & Null & Default \\
\hline Username & Varchar(15) & No & None \\
Password & Varchar(100) & No & None \\
Fullname & Varchar(50) & No & None \\
Job_title & Varchar(50) & No & None \\
Join_date & Timestamp & No & None \\
Last_activity & Timestamp & No & None \\
Status & Enum('1','2') & No & None \\
\hline
\end{tabular}

b) Tabel file

Tabel 2. Struktur tabel file

\begin{tabular}{llll}
\hline \multicolumn{1}{c}{ Field } & \multicolumn{1}{c}{ Type } & Null & Default \\
\hline Id_file & Integer(11) & No & None \\
Username & Varchar(15) & No & None \\
File_name_source & Varchar(255) & No & None \\
File_name_finish & Varchar(255) & No & None \\
File_url & Varchar(255) & No & None \\
File_size & Float & No & None \\
Password & Varchar(16) & No & None \\
Tgl_upload & Timesstamp & No & None \\
Status & Enum('1','2') & No & None \\
Keterangan & Varchar(255) & No & None \\
\hline
\end{tabular}

\subsection{Perancangan Antarmuka}

Perancangan antarmuka merupakan bagian dari input yang dirancang lebih detail dengan pembuatan sistem Dokumen. Perancangan ini berupa tampilan sistem. Dibawah ini merupakan perancangan antarmuka sistem:

a) Desain Screen login

Merupakan tampilan desain login untuk user. Desain screen user yang akan ditampilkan pada gambar 3 : 


\section{Keamanan Dokumen}

\begin{tabular}{|l|}
\hline \multicolumn{1}{|c|}{ Login } \\
Username \\
\hline Username \\
\hline Password \\
\hline Password Login \\
\hline Copyright 2020 - Yulieo \\
\hline
\end{tabular}

Gambar 3. Screen Login

b) Desain Screen Dashboard

Desain Screen dashboard merupakan tampilan utama screen user sistem dokumen. Desain screen dashboard untuk user dengan hak akses admin ditampilkan pada Gambar 4.

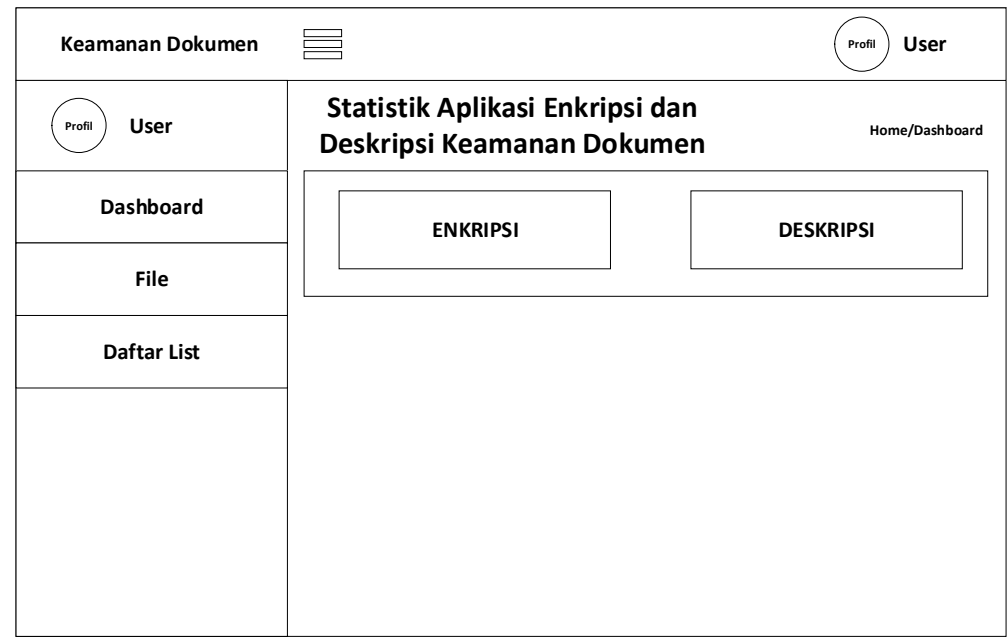

Gambar 4. Desain Screen Dashboard

c) Desain Screen Input Enkripsi

Desain Screen file merupakan tampilan screen file user sistem dokumen. Desain screen file untuk user ditampilkan pada Gambar 5.

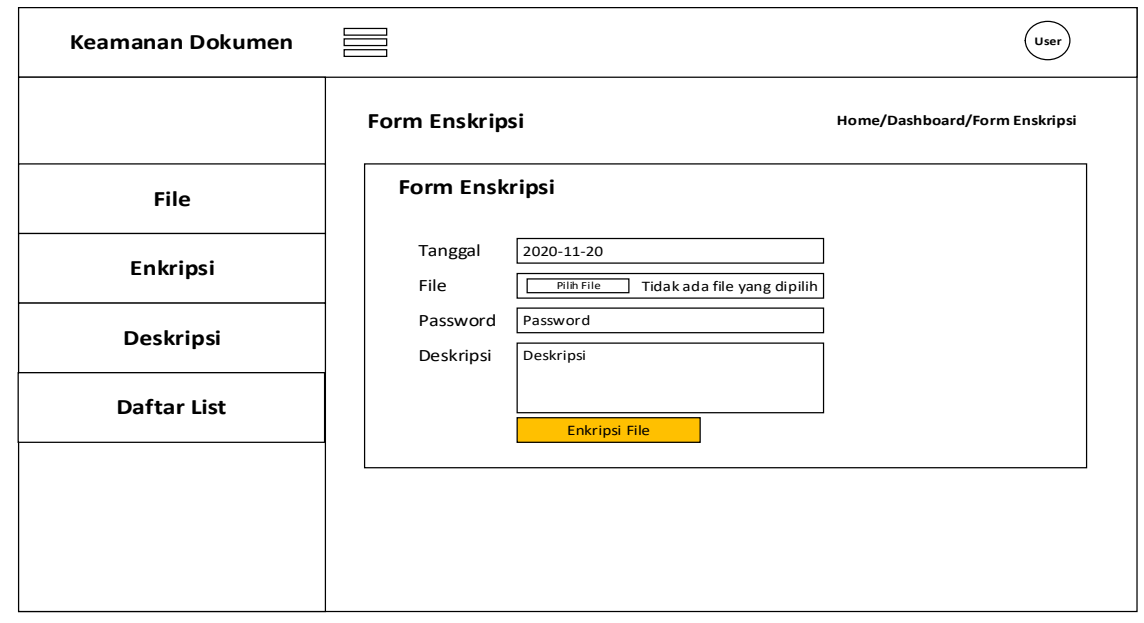

Gambar 5. Desain Screen File 
d) Desain Screen Input Deskripsi

Desain Screen Utama merupakan tampilan screen Enkripsi user sistem dokumen. Desain screen Enkripsi untuk user ditampilkan pada Gambar 6 .

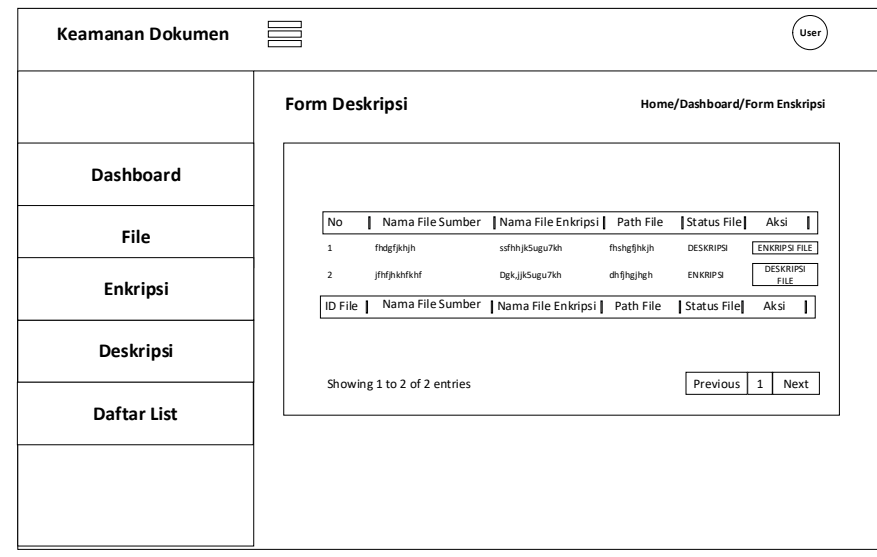

Gambar 6. Desain Screen Enkripsi

e) Desain Screen Daftar list

Desain Screen daftar list merupakan tampilan screen daftar list user sistem dokumen. Desain screen daftar list untuk user ditampilkan pada Gambar 7.

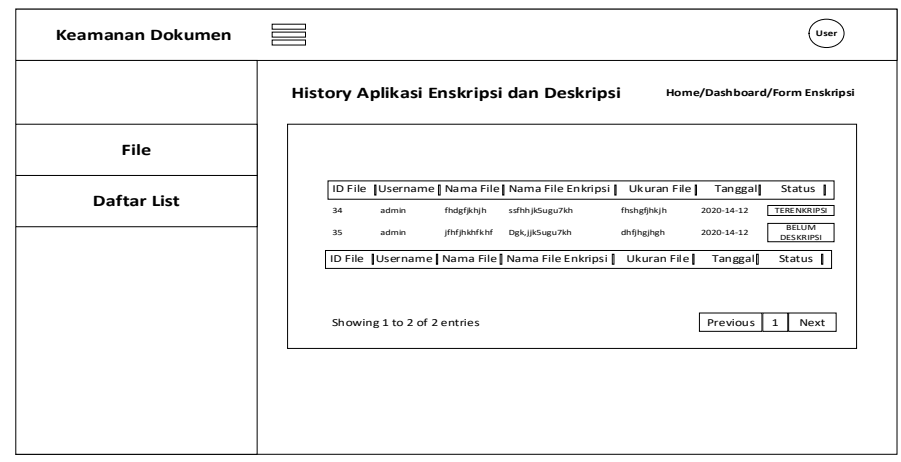

\section{Gambar 7. Desain Screen Daftar List}

\section{HASIL DAN PEMBAHASAN}

\subsection{Designer Sistem}

Sistem informasi keamanan dokumen menggunakan algoritma Advanced Encription Standard (AES). Implementasi database sistem ditunjukan pada gambar 8 .

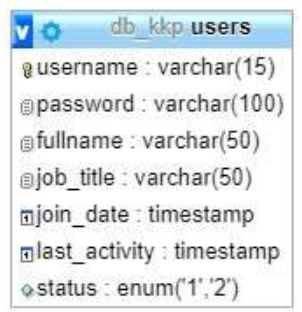

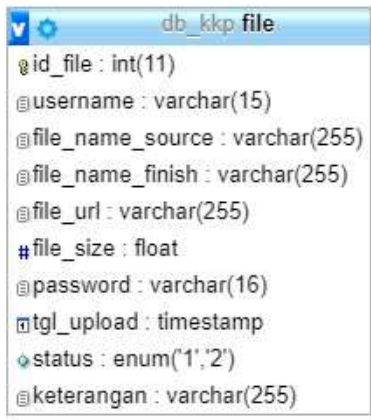

Gambar 8. Implementasi Database

\subsection{Implementasi Antarmuka}

Implementasi antarmuka merupakan hasil program berdasarkan sistem yang telah dirancang. Berikut dibawah ini implementasi antarmuka adalah sebagai berikut: 
a) Halaman Login

Merupakan tampilan desain login untuk user. Halaman screen user yang akan ditampilkan pada gambar 9.

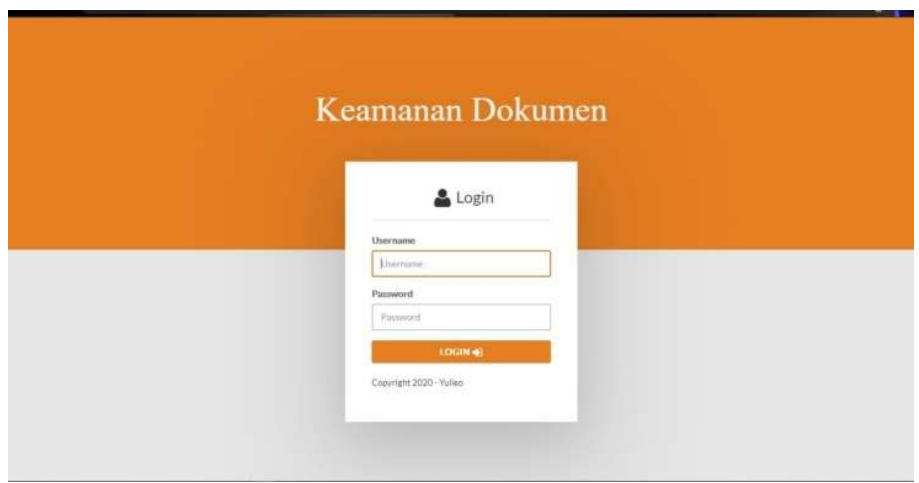

Gambar 9. Halaman Login

b) Halaman Dashboard

Halaman dashboard merupakan tampilan utama screen user sistem dokumen. Halaman screen dashboard untuk user dengan hak akses admin ditampilkan pada Gambar 10.

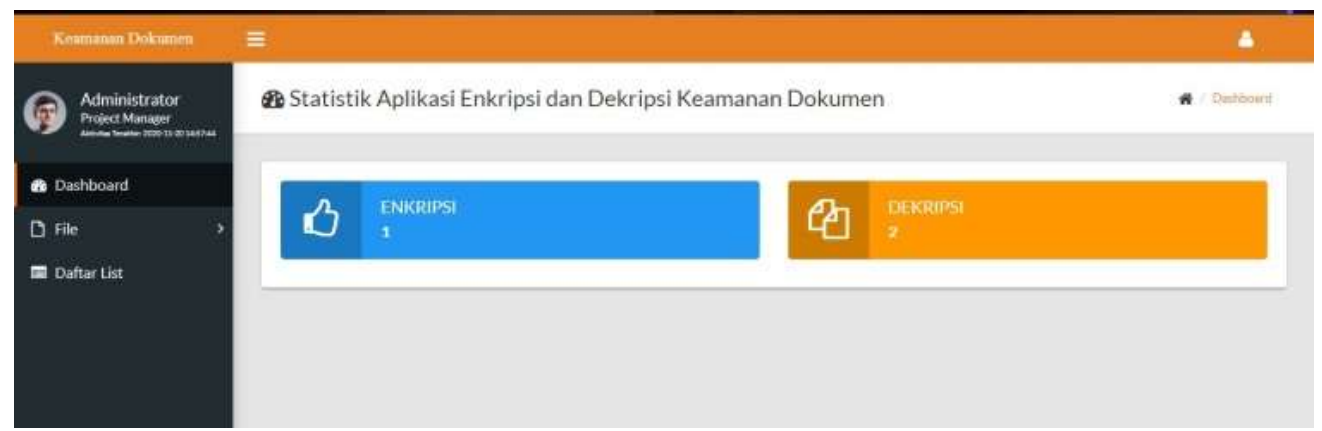

\section{Gambar 10. Halaman Dashboard}

c) Halaman File Enkripsi

Halaman file Enkripsi merupakan tampilan file Enkripsi untuk user sistem dokumen. Halaman file Enkripsi untuk user ditampilkan pada Gambar 11.

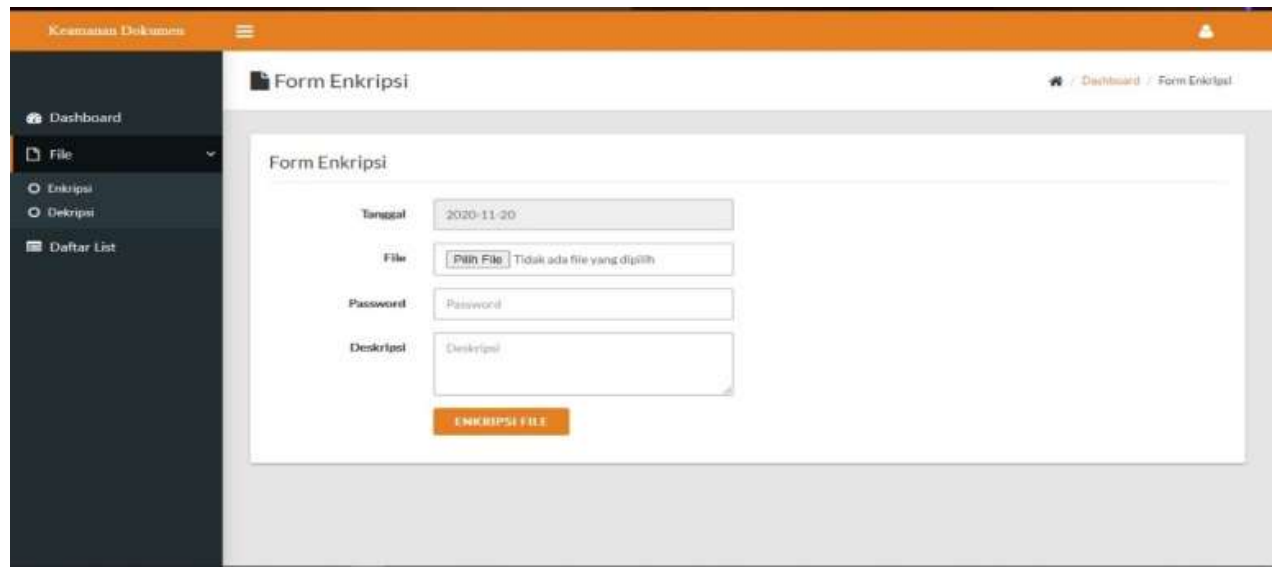

Gambar 11. Halaman File Enkripsi

d) Halaman File Deskripsi

Halaman file deskripsi merupakan tampilan file deskripsi user sistem dokumen. Halaman file deskripsi untuk user ditampilkan pada Gambar 12. 


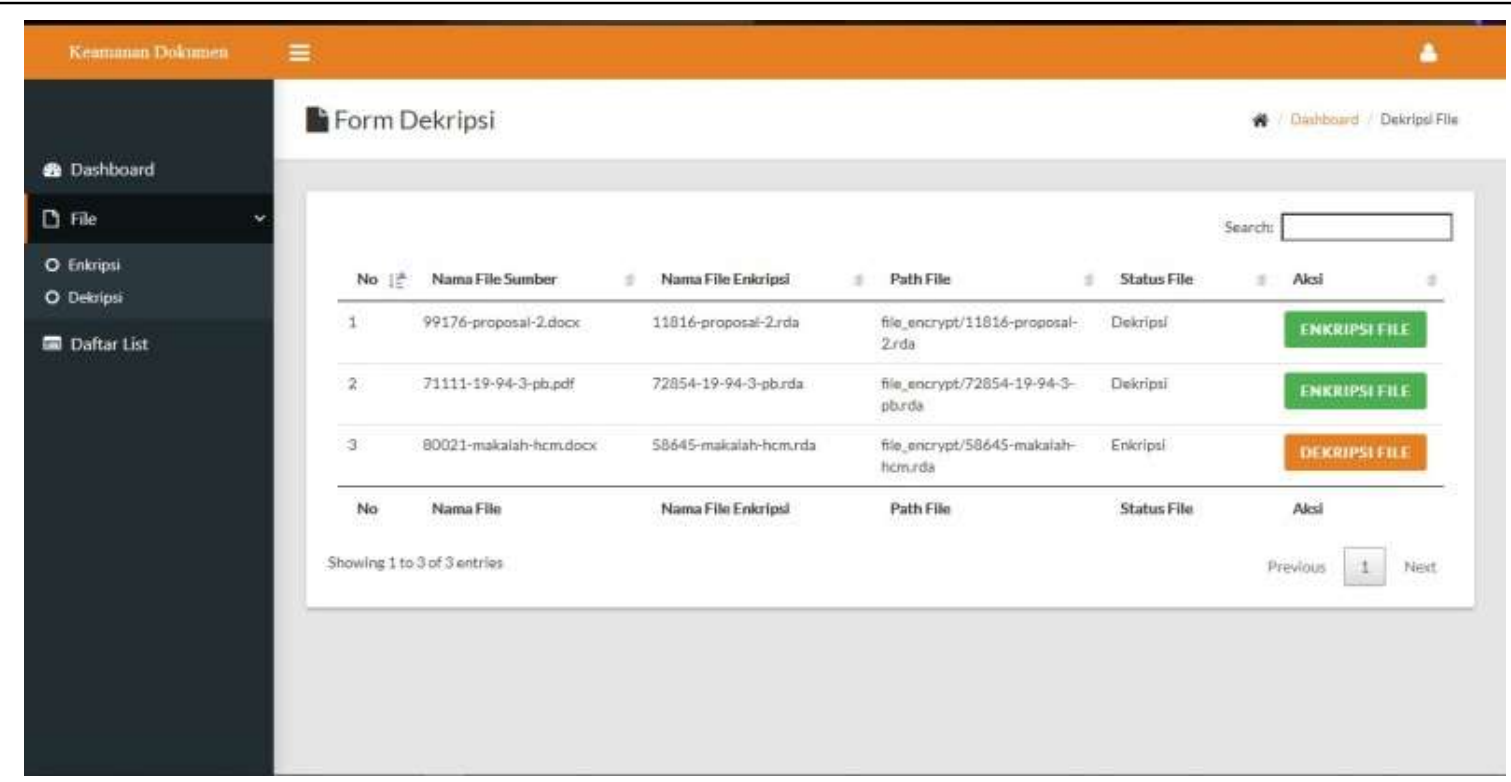

\section{Gambar 12. Halaman File Deskripsi}

e) Halaman Daftar List

Halaman daftar list merupakan tampilan screen daftar list user sistem dokumen. Halaman screen daftar list untuk user ditampilkan pada Gambar 13.

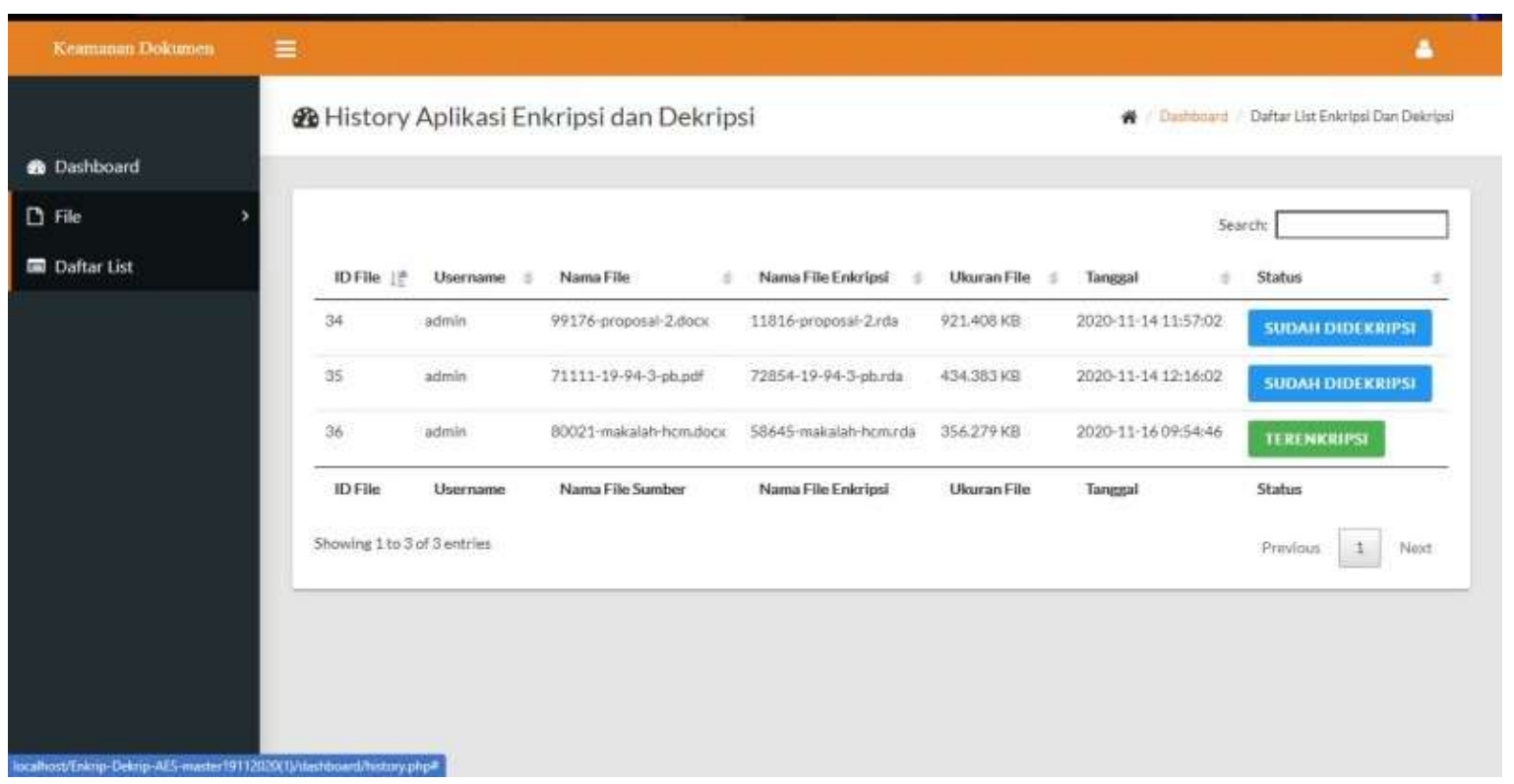

Gambar 13. Halaman Daftar List

\section{KESIMPULAN}

Berdasarkan hasil analisa dan perancangan, serta implementasi sistem dan pembahasan bab-bab sebelumnya, maka penelitian ini dapat diambil kesimpulan sebagai berikut :

a) Algoritma AES dapat dijadikan salah satu alternatif untuk proses keamanan data dalam hal ini enkripsi dan dekripsi file dokumen.

b) Ukuran file merupakan salah satu variabel yang cukup penting karena berpengaruh terhadap waktu proses enkripsi dan dekripsi. Pada variabel hasil, waktu merupakan tolak ukur dari proses, apakah terhitung cepat atau lambat dari ukuran file yang harus diproses.

c) File yang melalui uji coba enkripsi akan berubah bentuk menjadi file yang tak bisa dibaca, file dapat kembali kebentuk asli jika melalui proses dekripsi dengan menggunakan kunci yang sama saat enkripsi.

d) Dari hasil penelitian telah dibuktikan bahwa isi file awal yang mengalami proses enkripsi, kemudian mengalami proses dekripsi, maka akan kembali seperti file awal semula. 
Jurnal SITECH, Vol 3, No 2, Desember 2020

$P-I S S N$ : 2615-8531, E-ISSN : 2622-2973

\section{DAFTAR PUSTAKA}

[1] Mukhtar, H., (2018). Kriptografi untuk Keamanan Data. Deepublish.

[2] Sutabri, Tata. 2012. Analisis Sistem Informasi. Yogyakarta: Andi.

[3] Hariyanto, B. (2009). Sistem Operasi. Bandung : Informatika.

[4] Komputer, W., (2010). Panduan Belajar MySQL Database Server. Mediakita.

[5] Suprianto, D., (2008). Buku Pintar pemrograman php. Bandung: OASE Media.

[6] Ibrahim, A. A., (2017). Perancangan Pengamanan Data Menggunakan Algoritma AES (Advanced Encyption Standard). Jurnal Teknik Informatika STMIK Antar Bangsa, 3(1), 53-60. 